\title{
TRANSLATION
}

\author{
HOMER, ILIAD VII. 310-328.
}

In the Original Metre.

WHY is it, O Glaucus, we twain have honours above all men,

Foremost seats at a feast, good meat, and wine in abundance

Through Lycia, and, when men look on us, for gods they account us,

And a domain too is ours, broad fields there nigh to the Xanthus,

Cornlands and vinyards, rich tilth in bountiful acres?

Hence 'tis meet that of our Lycians we still be the foremost,

Standing first i' the ranks to encounter fiery fighting,

That some mail-coated Lycian may say when he sees us

'Nowise void of honour do our kings stand sovran amongst us

Through Lycia's townships and have fat sheep for a portion
And choice wine honey-sweet, nay but their might too appeareth

Most eminent, fighting foremost i' the ranks o' the people.'

Dear friend, an 'twere so that were this fight but avoided

Thenceforward for ever nor years nor death should assail us,

Nor would I here myself go forth to the front o' the fighting

Nor would I urge on thee to the fray where men win glory;

But, since now anyhow death's dooms stand alway about us

Countless, not to be shunn'd of a man nor shirkt, let us onward

Wheth'r some foe win glory from us or zee from a foeman.

John Sargeaunt.

\section{NEWS AND COMMENTS}

\section{THE WASPS.}

THE Wasps could hardly be put in the first class of Aristophanes' comedies as an acting play : the $a^{\prime} \gamma \omega \nu$ is somewhat long and tedious; the climax of the drama is an orgy which makes one regret for Philocleon the days when he was only jury-mad. But the Cambridge revival was fully justified, for we had a brilliant spectacle, some very creditable acting, and, above all, a most entertaining and masterly opera from the pen of Mr. Vaughan Williams. In this the best tendencies of the age seemed based on folk-music, while the disintegrating forces found their counterpart in the suggestions of Debussy. The fun of the play centred round the efforts of Philocleon to escape in the first act, round the dog-trial of the second act, which was somewhat weakened

NO. CCVII, VOL. XXIV. by the introduction of men dressed as kitchen utensils, instead of the pot and ladle, being themselves called on to give evidence, and round the artistic dancing of the young Messrs. Carcinus in the breakdown dance at the end. Mr. Robertson invested the part of Philocleon with marked individuality, making him indeed a humorous figure, but at the same time somewhat pathetic; it was an excellently studied part. Mr. Butler looked extremely well, and his delivery of his lines was good; but when not actually speaking, he suppressed himself too much, and seemed out of touch with what was going on around him-rather like an undergraduate visiting his college mission for the first time. The minor parts were, on the whole, well filled, but either the acoustic properties of the Cambridge Theatre leave 
something to be desired, or several of the actors were very indistinct. The chorus had many and complicated evolutions to perform, and were very ably led by $\mathrm{Mr}$. Pole, who displayed a certain businesslike ferocity admirably in keeping with the part.

B.

\section{MEDEA AT TERRY'S THEATRE.}

ThE Medea of Euripides has been lately played at Terry's Theatre by a company of Greeks, with the assistance of some English ladies, who constituted the bulk of the chorus. The audiences were meagre in the extreme; and the environment, during the performance witnessed by the present writer, was such as to make it impossible for the actors to do justice either to the play or to themselves. It would be unfair to criticise the acting.

The pronunciation was, of course, that of the modern Greek. Quantity was entirely disregarded; and no attempt whatever was made to give effect to the senarian rhythm. Nor did the rendering of the lyric parts of the drama compensate for the loss of the metrical and rhythmical beauties of the dialogue. The choruses of the Medea are for the most part in fairly simple dactylico-epitritic or logaoedic and dochmiac measures; but these were indiscernible; and it did not appear that the music was designed with any idea of conformity to the metres. It was quite otherwise at the careful and intelligent performance of the Electra of Sophocles given by ladies of the Bedford College at the Court Theatre last summer, when the dochmiacs in particular were rendered with the greatest precision, though too fast - a defect which was perhaps remedied at the recent repetition of the performance. It would seem that for the Medea there had not been sufficient time to train properly the ladies of the chorus. They stood in two rows, one on each side of the stage, during the whole performance, and they in fact took little or no part in the action of the play. It was an object-lesson of the necessity of rhythmical movement, as well as of music, for the purpose of giving due effect to the lyrics of a Greek drama, and to the part played by the chorus in its general evolution.

The Electra of Sophocles was subsequently given under conditions similar (it is understood) to those which attended the performance of Medea.

M. G. D.

\section{ARCHAEOLOGICAL RECORDS}

\section{EXCAVATIONS AT GELLYGAER.}

In the course of the summer the Garrison Baths of Gellygaer have been excavated by the Cardiff Naturalists' Society. The work was a corollary to their more important excavation (in the years 1899-I90I) of the Gellygaer camp itself, the interest and value of which were widely recognised by expert opinion at the time. The baths were an annexe of the camp, and have proved to be a very complete example of an establishment of the kind. One remarkable feature about the buildings, "which formed a block some I 12 feet long,' is that they were twice restored, and it is possible to trace both the original plan and the form which they finally assumed. Large parts of the hypocaust and many of the flue-tiles are still in situ. Among the finds were a variety of ornaments and coins, belonging chiefly to the reigns of Domitian and Trajan. Of greater importance were two fragmentary inscriptions, the larger of which fixes the date of occupation to Trajan's fifth consulship, and which, if restored, might run as follows :

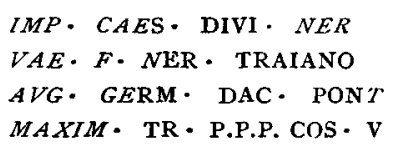

The left-hand portion of the slab, of which 